\title{
THE INFLUENCE OF SELECTED FACTORS ON ADOLESCENTS' CHOICE OF GRAPHICS AS A CAREER
}

\author{
Odji Ebenezer ${ }^{1}$ \\ Department of Industrial Design, \\ Federal University of Technology, Akure, Ondo State, Nigeria. \\ ezerodjimin@gmail.com \\ Rahman Adam ${ }^{2}$ \\ Department of Communication Design, \\ Kwame Nkrumah University of Science and Technology, Kumasi, Ghana. \\ rad2gh@gmail.com
}

\begin{abstract}
The Nigerian population of learners was still widely disadvantaged mostly due to the prevalence of poverty and, therefore, career choices were limited and governed by politics and strategies geared towards escaping the circle of growing economic retardation. Was the choice of graphics as a career path for young people also based mostly on the same or similar reasons? This study was aimed at determiningsome of the factors that influence adolescents' career choice with emphasis on graphics. Questionnaires were administered to 500 randomly selected students who met the selection criteria in southwestern Nigeria. The results showed that adolescents' awareness of the graphics discipline as well as the possession of inherent graphic related skills proved significant in influencing why young people choose graphics as a career. Therefore, it was recommended that proper awareness creation/orientations should be conducted about graphics to aid or guide potential students/trainees' choices. It was further recommended that the possession of graphics related skills in potential trainees should be considered during the admission processes into the discipline, although necessary skills may be developed by students during training.
\end{abstract}

Keywords: Adolescents, Awareness, Career Choice, Graphics, Inherent Skills, Nigeria 


\subsection{INTRODUCTION}

The making of career choicesis a complex decision for adolescents (Quinter \& Edwards, 2011). Therefore, it has been recommended that thoughtful attention should be given to the seeming challenge (Maree, Hislop-Esterhuizen, Swanepoel, \& van der Linde, 2009). Whether intending to be formerly trained or not, almost every individual is faced with the challenge of what occupational choice to make at one point or another in time. It is widely believed that selection of study programmes is a major factor in determining future career for young people (Sharif, Ahmad, \& Sarwar, 2019). The Nigerian population of learners, as at the time of this study, was still widely disadvantaged mostly due to poverty prevalence which leaves a population vulnerable (Odji, 2020), and, therefore, career choices were limited and governed by politics and strategies geared at escaping the circle of growing economic impedance. The decisions adolescents make about their work, occupations, and careers will significantly affect their future social relationships and leisure-time activities (Borg, 1996).

According to previous studies, while some young people make their career decisions at the secondary school level (e.g. physicians), others make theirs within the first or second year of tertiary education (Paolillo, 1982; Sale, 2001; Myburgh, 2005).The questions however are: Why do they eventually settle for what they eventually become? Why do people study graphics? Why do people choose their career path as opposed to other available alternatives? Are they random coincidences or are there specific factors influencing their choices? This study was aimed at deciphering selected factors that influence the choice of adolescents to choose graphics as a career path.

There are various factors that influence young people's choices of career. These factors might be intrinsic and extrinsic (Myburgh, 2005). Intrinsic factors have been defined as factors "that are related to satisfaction derived from a job that provides the opportunity to be creative and autonomous in an intellectually challenging and dynamic environment" (Ahmed, Alam, \& Alam, 1997; Myburgh, 2005). Extrinsic factors were viewed as more outward to the nature of the career in consideration such as remunerations or rewards and other market-related factors (Ahmed et al, 1997; Myburgh, 2005). Some of the factors/reasons are rather cross-cultural or interdisciplinary while others are more discipline specific.

Career choice has lately become a very complicated science attracting the curiosity of researchers (Nyamwange, 2016). Various studies have been conducted to satisfy the growing curiosity in why adolescents settle for a line of career and not another. Some of such studies are recorded in Table 1 with some of the factors mentioned or identified as having a form of link, either strong or weak, with the choices of career of adolescents. 
Table 1: Career related studies and some factors identified/mentioned as career influencing

\begin{tabular}{lll}
\hline S/N & STUDIES & FACTOR (S)
\end{tabular}

$1 \quad$ Abrahams, Jano, \& Burger (2015)

2 Ahmed, Alam, \& Alam (1997)

3 Borg (1996)

$4 \quad$ Fizer (2013)

$5 \quad$ Hauer, et al. (2008)

6 Kazi, Nimra, \& Nawaz (2017)

7 Kochanek \& Norgaard (1985)

$8 \quad$ Myburgh (2005)

9 Osipow (1983); Maree, Hislop-Esterhuizen, Swanepoel, \& van der Linde (2009)
- Visits from lecturers and

- Brochures

- Financial and market factors (i.e. Lucrativeness)

- Influence of the family

- Influence of peers

- Influence of the school itself

- Information available through school visits to places of work

- Work experience of students

- Availability of occupational information

- Demands for jobs

- Differences in age, gender, and personal characteristics

- Deliberate avoidance of extensive hard work by prospective candidates.

- Intellectual challenge of the course of study

- Interest in the subject

- Personality type and intrinsic factors of students

- Students counseling sessions

- Financial outcomes

- Financial constraints faced by individuals

- Resources at candidates' disposal

- Ease of subject

- Future job opportunities

- Job outcomes

- Job opportunities

- The quality of firm personnel

- Passion for the job

- Decision time-frame of career choice

- Socio-economic background

- Students' perceptions of the benefits/constraints of a profession

- Career expectations

- Potential facilitation in teaching

- Fringe benefits

- Financial considerations

- Discernible obstacles

- Geographic location 


\begin{tabular}{|c|c|c|}
\hline 10 & 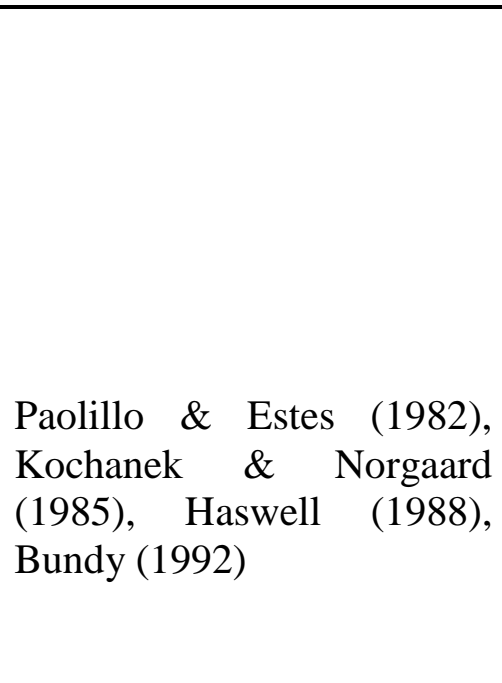 & $\begin{array}{l}\text { - Heredity } \\
\text { - Family history } \\
\text { - Socioeconomic status } \\
\text { - Family composition } \\
\text { - Parenting style } \\
\text { - Parents' attitude towards own career } \\
\text { - Opportunities for education and work } \\
\text { - Available financial resources. } \\
\text { - Job market considerations inclusive of: } \\
\text { - Job satisfaction } \\
\text { - Job security } \\
\text { - Job availability } \\
\text { - Job flexibility and } \\
\text { - Opportunities for short or long term advancements. }\end{array}$ \\
\hline 12 & Quinter \& Edwards (2011) & $\begin{array}{l}\text { - Availability of advancement opportunities } \\
\text { - } \text { Learning experiences } \\
\text { - } \text { Learning experiences } \\
\text { - } \text { Career flexibility } \\
\text { - } \text { Availability of advancement opportunity } \\
\text { - Opportunity to apply skills } \\
\text { - Personal interest or Self - desire } \\
\text { - Parental influence } \\
\text { - } \text { Future prospects } \\
\text { - Prestige } \\
\text { - } \text { Better salary }\end{array}$ \\
\hline
\end{tabular}

The above list is obviously not exhaustive. There are various other studies either debating the results of the above listed studies or corroborating them. Some others identify new factors entirely. The current study attempts to do both by selecting from the already identified factors, alongside new ones, as found unique to the field of graphics in the study area. Therefore, the following factors were selectively adopted for the study: awareness of graphics as a discipline, knowledge about the discipline, lucrativeness of the field of graphics, level of related inherent skills, likelihood to pursue a career in graphics or graphics related fields and the impact of gender on graphics as a choice of career. The nature of graphics as a science, an art based discipline or a mixture of both was also investigated.

\subsection{Awareness and Knowledge of graphics as a discipline}

Awareness, in the context of this study, is the knowledge or perception of a situation or facts about a particular line of career. According to aquasi-experimental study conducted within the nursing field, Career Awareness Sessions (CASs) had a significant effect on study variables (perceived career and talent development, self-efficacy and career barriers) (Hashish, 2019). This shows that awareness of the specific profession understudied had impact on the progress of the 
students. Odji (2020) and Odji (2020b) emphasised the significance of awareness in choices of actions and eventual behavioural adjustments. Therefore, the current study investigated the possible influence that awareness of the graphics discipline may have on the career choices of adolescents.

The line between awareness and knowledge is very thin. "Awareness means to know, to realise or be interested in knowing about something, or, to know that something is important" (Gafoor, 2012). In other words, awareness is having knowledge about something. Such knowledge, however, may not necessarily imply understanding of the subject in consideration (Gafoor, 2012). The implication of this is that it is possible for adolescents to be aware that a field exists and have routine ideas about happenings in the field, yet not have appropriate or detailed knowledge of the discipline. The existing level of knowledge of adolescents about graphics was therefore surveyed.

\subsection{Lucrativeness of the field of graphics}

Lucrativeness is closely linked with gainfulness and profitability or the ability to afford an individual some forms of benefits, which may or may not be economic in nature and context. As insinuated by Ahmed et al. (1997), financial, economic and market factors (including the marketability of the skill-sets within a field), constitute the lucrativeness of such field of study or career path. The opinion of adolescents was therefore surveyed about the lucrativeness of graphics as a profession with a view to providing a leverage for deciphering how the opinion they hold may impact on their career choices.

\subsection{Level of related inherent skills and likelihood to pursue a career in graphics}

Within the context of this study, graphics related skills include drawing, painting, computer aided design or content creation, illustration, symbolism and such like, all of which were skillsets to which students might have been exposed right from their high/secondary school days. Likelihood to pursue a career is simply the probability of choosing a field as a career path. This probability was obtained with disregard for possible discrete choice alternatives. This was premised on the assumption of the independence of irrelevant alternatives axiom which holds that the relative odds of two choice alternatives will not be altered by the addition or removal of other alternatives from the choice set (Bunch, 1987).

\subsection{The nature of the field of graphics}

Graphics has been, for a very long time, by various studies, reflected as an Art based discipline although such relations have been directed towards the environment (e.g. Oladumiye \& Olabiyi, 2015; Odji, 2019), health (e.g. Odji, 2019b; Odji, 2020c), computer graphics (e.g. Eck, 2018) and engineering (e.g. Odji, 2018) areas and so on which tended to present the field as science based. Such conflicting reflections have caused many to assume that graphics is a blend of both art and science as reflected in other studies (e.g. Ario, Odji, \& Odewole, 2020). While graphics is established already as a multidisciplinary field of study and career, the perceptions of adolescents were also surveyed as well as the possible impact such perceptions may portend for their career choices relating to graphics. 


\subsection{METHODOLOGY}

A non-experimental design (survey design; administering a non-standardised questionnaire) was adopted. As noted earlier, some young people make their career decisions at the secondary school level (Paolillo, 1982; Sale, 2001; Myburgh, 2005). Therefore, secondary level adolescents, from South West Nigeria, were adopted for the current study. A mixed method of sampling was adopted. Criterion sampling was adopted for limiting the range of students that can be involved in the study. The criteria included: 1 . Respondent must be adolescents not older than 19 nor younger than 10. The World Health Organisation (WHO) defined adolescents as individuals between ages 10-19 (WHO, N.D). 2. Respondents must be in the senior secondary school class. Schools were chosen to provide for easy access to the target population. They were an amalgamation of members of the target population of the study in a particular location (with adopted classes and qualified class members serving as focus groups) from different regions of the study area. All sections of the senior secondary school (science, art and commercial, as it existed in the study area) were covered. Students sampled had to meet the criteria stipulated. $45 \%$ of the respondents were males while the remaining 55\% were females. This was not deliberate. It merely reflects the increasing enrolment of the female gender in the South-Western part of Nigeria in schools. Based on the above stated parameters, 500 respondents were sampled in total.

\subsection{Research Questions}

The following research questions guided the study:

1. Is there any significant relationship between adolescents' awareness of graphics as a discipline and their prospective choice of career in the same field?

2. Is there any significant relationship between gender and prospective choice of career in graphics amongst adolescents?

3. What is the perception of students on graphics based on lucrativeness of the discipline?

4. Is there any significant relationship between students' present arm of study (that is, art, commercial or science) in Secondary/high School and their prospective interest in graphics as a career choice?

5. Is there any significant relationship between students' inherent skill or level of inherent skill and their prospective interest in graphics design as a career choice?

\subsection{Research Hypotheses}

The following null hypotheses were proposed for the study:

$\mathrm{H}_{\mathrm{O} 1}$ : There is no significant relationship between awareness of graphic design as a discipline and likelihood to pursue a career in graphics

$\mathrm{H}_{\mathrm{O} 2}$ : There is no significant relationship between students' gender and their prospective choice of graphics as a career 
Journal DOI: 10.46654/ij.24889849

Article DOI: 10.46654/ij.24889849.a6111232

$\mathrm{H}_{\mathrm{O} 3}$ : There is no significant relationship between students' present arm of study (that is, art, commercial or science) in Secondary School and their prospective interest in graphics as a career choice

$\mathrm{H}_{\mathrm{O} 4}$ : There is no significant relationship between students' inherent skill (or level of inherent skill) and their prospective interest in graphics as a choice of career

\subsection{Data Collection and Analysis}

Non-standardisedquestionnaire, supported by one-on-one and group interviews, was used for the collection of data. Descriptive statistics including frequencies and percentages were used for the presentation of the collected data. Chi-Square statistics was adopted for the testing of the hypotheses. Chi-Square is expressed thus:

$$
X^{2}=\sum \frac{\left(O_{i}-E_{i}\right)^{2}}{E_{i}}
$$

Where $X^{2}=$ Chi-Square, $O_{i}=$ Observed frequencies and $E_{i}=$ Expected frequencies.

\subsection{RESULTS, ANALYSIS AND DISCUSSION}

Adolescents were sampled based on the following: awareness of the discipline, knowledge of the discipline, lucrativeness of the field of graphics, level of related inherent skills, likelihood to pursue a career in graphics or graphics related fields and the impact of gender on graphics as a choice of career. Their opinions were also weighed on the nature of the field as science, art or mixed based. The results were as presented in Table 2 . 


\subsection{Results}

Table 2: Opinion survey results on graphics

\begin{tabular}{|c|c|c|c|c|}
\hline $\mathbf{S} / \mathbf{N}$ & VARIABLE & & & \\
\hline 1 & Awareness of the Discipline & $\begin{array}{l}\text { Positive } \\
342(68.4 \%)\end{array}$ & $\begin{array}{l}\text { Negative } \\
158(31.6 \%)\end{array}$ & $\begin{array}{l}\text { Undecided } \\
0(0 \%)\end{array}$ \\
\hline 2 & Knowledge of the Discipline & $\begin{array}{l}\text { High } \\
106(21.2 \%)\end{array}$ & $\begin{array}{l}\text { Moderate } \\
240(48.0 \%)\end{array}$ & $\begin{array}{l}\text { Low } \\
154(30.8 \%)\end{array}$ \\
\hline 3 & $\begin{array}{l}\text { Level of related Inherent } \\
\text { Skill }\end{array}$ & $\begin{array}{l}\text { High } \\
81(16.2 \%)\end{array}$ & $\begin{array}{l}\text { Moderate } \\
213(42.6 \%)\end{array}$ & $\begin{array}{l}\text { Low } \\
206(41.2 \%)\end{array}$ \\
\hline 4 & $\begin{array}{l}\text { Likelihood to pursue career } \\
\text { in graphics }\end{array}$ & $\begin{array}{l}\text { Positive } \\
\text { likelihood } \\
265(53.0 \%)\end{array}$ & $\begin{array}{l}\text { Negative } \\
\text { likelihood } \\
235(47.0 \%)\end{array}$ & $\begin{array}{l}\text { Undecided } \\
0(0 \%)\end{array}$ \\
\hline 5 & Opinion on lucrativeness & $\begin{array}{l}\text { Lucrative } \\
328(65.6 \%)\end{array}$ & $\begin{array}{l}\text { Not Lucrative } \\
112(22.4 \%)\end{array}$ & $\begin{array}{l}\text { Undecided } \\
60(12.0 \%)\end{array}$ \\
\hline 6 & $\begin{array}{l}\text { Gender Predominance or } \\
\text { orientation }\end{array}$ & $\begin{array}{l}\text { Male Oriented } \\
136(27.2 \%)\end{array}$ & $\begin{array}{l}\text { Female } \\
\text { Oriented } \\
18(3.6 \%)\end{array}$ & $346(69.2 \%)$ \\
\hline 7 & $\begin{array}{l}\text { Opinion on nature of } \\
\text { Discipline }\end{array}$ & $\begin{array}{l}\text { Science based } \\
108(21.6 \%)\end{array}$ & $\begin{array}{l}\text { Art based } \\
152(30.4 \%)\end{array}$ & $\begin{array}{l}\text { Both science } \\
\text { and art based } \\
240(48.0 \%)\end{array}$ \\
\hline
\end{tabular}

As shown in Table 2, a higher percentage (68.4\%) of the respondents was appropriately aware of graphics as a field of study and possible career path. However, actual knowledge of the field was merely moderate as only $21.2 \%$ of the respondents had high enough knowledge of graphics as a field of study and practice. As mentioned earlier, awareness is having knowledge about something that may however not necessarily imply understanding of the subject in consideration (Gafoor, 2012). This accentuates the significance of proper orientation or awareness creation for the achievement of appropriate level of apposite knowledge. 
More than half of those surveyed had inherent graphics related skills such as drawing. $42.6 \%$ of the respondents only had moderate or trace inherent graphics related skills while over $41 \%$ had ignorable or no inherent graphics related skills. When asked to indicate their opinion on which gender they felt should appropriately practice graphics, irrespective of skill level, the majority felt the field is both male and female dominated and, therefore, not gender bias. However, 27.2\% of the respondents were of the opinion that graphics was more of a male dominated/oriented field as opposed to only $3.6 \%$ of the respondents who felt that graphics was a female dominated field. Does that mean graphics tends more towards the male gender? This was tested in the study hypothesis 2 .

On the nature of graphics as a science or art discipline, the highest percentage of $48 \%$ opined that graphics was both a science and an art (multidisciplinary) discipline. However, amongst those who felt the discipline was either an art based or science based discipline, more of the respondents, $30.4 \%$ as opposed to $21.6 \%$, opined that it was more of an art discipline than a science discipline.

In terms of financial and market factors, job market considerations inclusive as indicated in Table 1, the highest percentage, $65.6 \%$, of the respondents were of the opinion that graphics was lucrative. $12 \%$ of the respondents were however undecided on the lucrativeness of graphics as a career choice.

On the likelihood of the surveyed adolescents pursuing a career in graphics, the majority of the respondents, $53.0 \%$, indicated tendencies to pursue a career in graphics. The remaining $47 \%$ of the respondents were quick to indicate otherwise.

The results presented in Table 1 shows that the investigated factors may have some level of impact on adolescents' choice of graphics as a career path. It however does not indicate how significantly they may impact on the young peoples' likelihood to choose or reject graphics as a career.

\subsection{Hypotheses Testing}

Chi-Square statistics was used for the testing of the hypotheses of the study as follow:

\section{Hypothesis 01}

$\mathrm{H}_{\mathrm{O} 1}$ : There is no significant relationship between awareness of graphic design as a discipline and likelihood to pursue a career in graphics

$\mathrm{H}_{\mathrm{A} 1}$ : There is a significant relationship between awareness of graphic design as a discipline and likelihood to pursue a career in graphics 
Journal DOI: 10.46654/ij.24889849

Vol. 6, Issue 11 (November, 2020) |www.ijaar.org

Article DOI: 10.46654/ij.24889849.a6111232

Table 3: Relationship between respondents' awareness of graphics and their choice of career in graphics

\section{Aware of Discipline $\quad$ Not Aware of $\quad$ Row totals}

Discipline

\begin{tabular}{llll}
\hline $\begin{array}{l}\text { Likely to Pursue a } \\
\text { career in graphics }\end{array}$ & 243 & 99 & 342 \\
$\begin{array}{l}\text { Not Likely to pursue } \\
\text { a career in graphics }\end{array}$ & 22 & 136 & 158 \\
\begin{tabular}{l} 
Column totals \\
\hline
\end{tabular} & $\mathbf{2 5 6}$ & $\mathbf{2 3 6}$ & Grand Total = 500 \\
\hline
\end{tabular}

$\chi 2=141.5945, d f($ degree of freedom $)=1, \chi^{2} / d f=141.5942, \mathrm{P}\left(\chi^{2}>141.5945\right)=0.00001$. Hence, the null hypothesis is rejected while the alternative hypothesis which established an association between awareness and the likelihood to pursue a career in graphics is accepted. Therefore, we conclude that there is a significant relationship between awareness of graphic design discipline and likelihood to pursue a career in graphics.

\section{Hypothesis 02}

$\mathrm{H}_{\mathrm{O} 2}$ : There is no significant relationship between students' gender and their prospective choice of graphics as a career

$\mathrm{H}_{\mathrm{A} 2}$ : There is no significant relationship between students' gender and their prospective choice of graphics as a career

Table 4: Relationship between gender of respondents and their choice of career in Graphics

\begin{tabular}{llll}
\hline & Male & Female & Row totals \\
\hline $\begin{array}{l}\text { Likely to Pursue a } \\
\text { career in graphics }\end{array}$ & 126 & 139 & 265 \\
$\begin{array}{l}\text { Not Likely to pursue } \\
\text { a career in graphics }\end{array}$ & 101 & 134 & 235 \\
\begin{tabular}{l} 
Column totals \\
\hline
\end{tabular} & $\mathbf{2 2 7}$ & $\mathbf{2 7 3}$ & Grand Total = 500 \\
\hline
\end{tabular}

$\chi^{2}=1.0487, \mathrm{df}=1, \chi^{2} / \mathrm{df}=1.0487, \mathrm{P}\left(\chi^{2}>1.0487\right)=0.305817$. Hence, the null hypothesis is accepted while the alternative hypothesis which established an association between students' gender and the likelihood to pursue a career in graphics is rejected. Therefore, we conclude that there is no significant relationship between gender and likelihood of students to pursue a career in graphics. This means that anyone/student is likely to pursue a career in graphics irrespective of gender. 


\section{Hypothesis 03}

$\mathrm{H}_{\mathrm{O} 3}$ : There is no significant relationship between students' present arm of study (that is, art, commercial or science) in Secondary School and their prospective interest in graphics as a career choice

$\mathrm{H}_{\mathrm{A} 3}$ : There is a significant relationship between students' present arm of study (that is, art, commercial or science) in Secondary School and their prospective interest in graphics as a career choice

Table 5: Association between arm of study of respondents and their choice of career in Graphics

\begin{tabular}{llll}
\hline & Positive Likelihood & Negative Likelihood & Row totals \\
\hline Science & 145 & 157 & 302 \\
Commercial & 34 & 16 & 50 \\
Art & 86 & 62 & 148 \\
Column totals & $\mathbf{2 6 5}$ & $\mathbf{2 3 5}$ & Grand Total $=\mathbf{5 0 0}$ \\
\hline
\end{tabular}

$\chi^{2}=9.0814, d f=2, \chi^{2} / d f=4.54, \mathrm{P}\left(\chi^{2}>9.0814\right)=0.10666$. Hence, the null hypothesis is accepted while the alternative hypothesis which established an association between students' present arm of study and the likelihood to pursue a career in graphics is rejected. Therefore, we conclude that there is no significant relationship between students' present arm of study and their likelihood to pursue a career in graphics.

\section{Hypothesis 04}

$\mathrm{H}_{\mathrm{O} 4}$ : There is no significant relationship between students' inherent skill (or level of inherent skill) and their prospective interest in graphics as a choice of career

$\mathrm{H}_{\mathrm{O} 4}$ : There is a significant relationship between students' inherent skill (or level of inherent skill) and their prospective interest in graphics as a choice of career

Table 6: Relationship between level of inherent skill of respondents and their choice of career in Graphics

\begin{tabular}{llll}
\hline & Positive Likelihood & Negative Likelihood & Row totals \\
\hline High & 34 & 47 & 81 \\
Moderate & 124 & 89 & 213 \\
Low & 107 & 99 & 206 \\
Column totals & $\mathbf{2 6 5}$ & $\mathbf{2 3 5}$ & Grand Total $=\mathbf{5 0 0}$ \\
\hline
\end{tabular}

$\chi^{2}=6.3712, \mathrm{df}=2, \chi 2 / \mathrm{df}=3.19, \mathrm{P}\left(\chi^{2}>6.3712\right)=0.041353$. Hence, the null hypothesis is rejected while the alternative hypothesis which established an association between the level of inherent skills of students and their likelihood to pursue a career in graphics is accepted. Therefore, we conclude that there is a significant association between students' level of inherent skills and their likelihood to pursue a career in graphics. 


\subsection{SUMMARY OF FINDINGS}

1) There was a significant relationship between awareness of graphics as a discipline and the likelihood of adolescents to pursue a career in graphics.

2) There was a significant association between students' level of inherent graphic related skills and their likelihood to pursue a career in graphics.

3) There was no significant relationship between gender and the likelihood of adolescents to pursue a career in graphics. Therefore, adolescents are likely to pursue a career in graphics irrespective of gender.

4) There was also no significant relationship between students' existing or previous art or science orientation and their likelihood to pursue a career in graphics.

5) Adolescents' awareness of the graphics discipline as well as the possession of inherent graphic related skills proved significant in influencing why young people choose graphics as a career path.

\subsection{CONCLUSION}

Although, career choices have been limited and governed by politics and strategies geared towards escaping the circle of growing economic disadvantages especially in developing societies, related inherent skills and awareness/knowledge of the field plays significant roles in helping adolescents decide for or against choosing graphics as a career. Therefore, these factors should be put into consideration during career decision making as well as recruitment.

\subsection{RECOMMENDATIONS}

Based on the findings of this study as well as relevant previous studies, this study therefore proposed the following recommendations:

- Proper awareness creation should be carried out on graphics or any other field of study as awareness is significantly associated with the choice of career for adolescents.

- More satisfaction is derivable from a course of study when expectations are met. Satisfied expectations are more easily noticeable, identified with and appreciated by the candidates when their initial decisions were based on appreciable knowledge of the field. Therefore, proper orientations should be conducted about graphics to aid or guide potential students/trainees' choices. The availability of information about possible occupations as well as the implications of choosing a specific career contributes to the decision making process of adolescents (Maree et al., 2009).

- Teachers and guidance counselors should consider inherent skills in providing career advice.

- Although, necessary skills may be developed by students during training, yet, the possession of graphics related skills in trainees should be considered during the admission processes into the discipline. 


\section{REFERENCE}

Abrahams, F., Jano, R., \& Burger, V. L. (2015). Factors Influencing the Career Choice of Undergraduate Students at a Historically Disadvantaged South African University. 29(3), https://doi.org/10.5367/ihe.2015.0253.

Ahmed, K., Alam, K. F., \& Alam, M. (1997). An empirical study of factors affecting students' career choice in New Zealand. Accounting Education: An International Journal, 6(4), 325-335.

Ario, B. C., Odji, E., \& Odewole, O. P. (2020, September). An overview of the state of industrial design education in Nigeria: The limitations and prospects. Australian Journal of Science and Technology, 4(3), 339-347. http://aujst.com/vol-4-3/07_AJST_2020-19.pdf.

Borg, R. (1996). Factors Determining Career Choice. European Education, 28(2), 6-20. DOI: 10.2753/EUE1056-493428026.

Bunch, D. S. (1987, January). Maximum Likelihood Estimation of Probabilistic Choice Models. Siam J. Sci. Stat. Comput., 8(1), 56-70. https://epubs.siam.org/doi/pdf/10.1137/0908006.

Bundy, P. \&. (1992). What accounting students consider important in the job selection process. Journal of Applied Business Research, Spring 8(2), 1-8.

Eck, D. J. (2018). Introduction to Computer Graphics (Vol. Version 1.2). Geneva, NY: Hobart and William Smith Colleges.

Fizer. (2013). Factors Affecting Career Choices of College Students Enrolled in Agriculture. A Research Paper Presented for the Master of Science in Agriculture and Natural Resources Degree, The University of Tennessee, Martin.

Gafoor, K. A. (2012, November 12). Considerations in the Measurement of Awareness. National Level Seminar on Emerging Trends in Education. Retrieved December 22, 2020, from files.eric.ed.gov: https://files.eric.ed.gov/fulltext/ED545374.pdf

Hashish, E. A. (2019). The effect of career awareness on perceived career and talent development self-efficacy and career barriers among nursing students. Journal of Research in Nursing, 24((3-4)), 233-247. https://doi.org/10.1177/1744987118807259.

Haswell, S. \&. (1988). Accounting graduate employment choice. The Chartered Accountant in Australia, 53(2), 63-67.

Hauer, K. E., Durning, S. J., Kernan, W. N., Fagan, M. J., Mintz, M., O’Sullivan, P. S., et al. (2008, September 10). Factors Associated With Medical Students' Career Choices Regarding Internal Medicine. JAMA, 300(10), 1154-1164. doi:10.1001/jama.300.10.1154.

Kazi, A. A., Nimra, S., \& Nawaz, A. (2017). Factors Influencing Students' Career Choices: Empirical Evidence from Business Students. Journal of Southeast Asian Research, 2017(2017), 1-15. DOI: 10.5171/2017.718849. 


\section{Article DOI: 10.46654/ij.24889849.a6111232}

Kochanek, R. F., \& Norgaard, C. T. (1985). Student perceptions of alternative accounting careers - Part 1. The CPA Journal, 55(5), 36-43.

Maree, J. G., Hislop-Esterhuizen, N., Swanepoel, A., \& van der Linde, M. J. (2009). Factors Affecting the Career Choice of First-Year Student Teachers. International Journal of Adolescence and Youth, 15(1-2), 39-79. DOI: 10.1080/02673843.2009.9748020.

Myburgh, J. E. (2005). An empirical analysis of career choice factors that influence first-year Accounting students at the University of Pretoria: A cross-racial study. Meditari : Research Journal of the School of Accounting Sciences, 13(2), $35 \quad$ - 48. https://hdl.handle.net/10520/EJC72503.

Nyamwange, J. (2016). Influence of Student's Interest on Career Choice among First Year University Students in Public and Private Universities in Kisii County, Kenya. Journal of Education and Practice, 7(4), 96-102. https://files.eric.ed.gov/fulltext/EJ1092415.pdf.

Odji, E. (2018). Application of Design Principles and Theories for Achieving Optimized Aesthetics in Designs and Electrical Installations. (N. B. Vakada, Ed.) International Journal of Engineering and Modern Technology, 4(3), 78-93. https://iiardpub.org/get/IJEMT/VOL.\%204\%20NO.\%203\%202018/Application\%20of\%2 ODesign.pdf.

Odji, E. (2019). Aesthetics Application in Solid Waste Management as a Means of Optimising Environmental Sustainability in Urbanizing Third-World Environments. International Journal of Engineering and Manufacturing(IJEM), 9(4), 15-32. DOI:10.5815/ijem.2019.04.02.

Odji, E. (2019, January 08). Graphic Design Principles and Theories Application in Rendering Aesthetic and Functional Installations for Improved Environmental Sustainability and Development. International Journal of Engineering and Manufacturing, 2019(1), 21-37.

Odji, E. (2019b). Abuse by Design: The Implications and Prospects of Adopting Child-Character Centred Persuasive Designs and Systems. International Journal of Health and Pharmaceutical Research, 5(2(2019)), 31-48.

Odji, E. (2020, May). Curbing Covid-19 Prevalence and Other Communicable Diseases: The Laxity of Non-Local-Evidence-Based Awareness Creation. International Journal of Advanced Academic Research | Sciences, Technology and Engineering, 6(5), 66-80. DOI: 10.46654/ij.24889849.e6528.

Odji, E. (2020). Identifying Notable Threats to the Sustainability of African Art And Culture. African Journal of Culture, History, Religion and Traditions, 2(1), 28-49.

Odji, E. (2020b, June). Limiting the Community Transmission of Communicable Disease Outbreaks through Local-Evidence-Based Awareness Creation. International Journal of Advanced Academic Research (Sciences, Technology and Engineering), 6(6), 12-31 DOI: 10.46654/ij.24889849.e6618. 
Odji, E. (2020c). Roles of Children in the Proliferation of Communicable Diseases in Nigerian Rural Communities: A Designer's Perspective. International Journal of Health and Pharmaceutical Research, 5(3), 7-28. DOI: 10.5281/zenodo.3881081.

Oladumiye, E. B., \& Olabiyi, A. T. (2015). The Impact of Graphic Design and Art Works on Environmental Aesthetic. The International Journal of the Constructed Environment, 6(1), 13-28. DOI: 10.18848/2154-8587/CGP/v06i01/37438.

Osipow, S. (1983). Theories of career development (2nd ed.). In 2005. Multicultural career counselling: Theoretical applications of the systems theory framework. (N. Arthur, \& M. McMahon, Eds.) Career Development Quarterly, 53(13), 208-223.

Paolillo, J. \&. (1982). An empirical analysis of career choice factors among accountants, attorneys, engineers, and physicians. The Accounting Review, 57(4), 785-793.

Paolillo, J., \& Estes, R. (1982). An empirical analysis of career choice factors among accountants, attorneys, engineers, and physicians. The Accounting Review, 57(4), 785793.

Quinter, M., \& Edwards, K. (2011, April 1). Factors influencing students career choices among secondary school students in Kisumu municipality, Kenya. Journal of Emerging Trends in Educational Research and Policy Studies, 22, 81-87(7). https://www.ingentaconnect.com/content/sabinet/sljeteraps/2011/00000002/00000002/art 00001.

Sale, M. L. (2001). Steps to preserving the profession. National Public Accountant, 46(2), 810,19 .

Sharif, N., Ahmad, N., \& Sarwar, S. (2019, August 4). Factors Influencing Career Choices. IBT Journal of Business Studies Volume, 15(1), 33-46. https://ssrn.com/abstract=3431911.

Umar, I. (2014). Factors Influencing Students' Career Choice in Accounting: The Case of Yobe State University. Research Journal of Finance and Accounting, 5(17), 59-62.

WHO. (N.D). Adolescent Health in the South-East Asia Region. (World Health Organization (WHO)/South East Asia) Retrieved December 11, 2020, from who.int: https://www.who.int/southeastasia/health-topics/adolescent-health 